\title{
molecules
}

ISSN 1420-3049

http://www.mdpi.org

\section{3-(2-Alkylsulfanyl-6-benzothiazolylaminomethyl)-2-benzoxazo- lethiones - Synthesis and Photosynthesis-Inhibiting Activity in Spinach Chloropasts}

\section{Eva Sidoova, Katarina Kralova and Dusan Loos*}

Institute of Chemistry, Faculty of Natural Sciences, Comenius University, Mlynska dolina CH-2, SK84215 Bratislava, Slovakia. Tel. +421 7 60296342, Fax +421 7 65429064, E-mail loos@fns.uniba.sk

*Author to whom correspondence should be addressed.

Received: 12 May 1998 / Accepted: 5 March 1999 / Published: 29 March 1999

\begin{abstract}
The synthesis and photosynthesis-inhibiting activity of 14 new 3-(2-alkylsulfanyl6-benzothiazolylaminomethyl)-2-benzoxazolethiones are reported. The new compounds were prepared by the reaction of 2-alkylsulfanyl-6-aminobenzothiazoles with 3-hydroxymethyl-2benzoxazolethione. The structures of the compounds were verified by ${ }^{1} \mathrm{H}$ NMR spectra. The compounds inhibit photosynthetic electron transport in spinach chloroplasts. The photosynthetic activity was found to depend on the calculated lipophilicity of the new compounds. Some structure characteristics and quantum chemical parameters were calculated by AM1 method.
\end{abstract}

Keywords: Photosynthetic electron transfer inhibition, AM1 quantum chemical method, QSAR, calculated lipophilicity, 3-(2-alkylsulfanyl-6-benzothiazolylaminomethyl)-2benzoxazolethiones.

\section{Introduction}

Benzothiazole derivatives have shown a large scale of biological activities. 2-Alkylsulfanyl-6aminobenzothiazoles [1] and their derivatives substituted at the amino group [2] are of interest both for agricultural and pharmaceutical chemistry.

(C) 1999 MDPI. All rights reserved. 
3-(2-Alkylsulfanyl-6-benzothiazolylaminomethyl)-2-benzothiazolethiones [3] have shown antifungal and anticandidous $[4,5]$ activities. The compounds were not stable enough on longer storing. Replacing one sulphur atom in the heterocyclic system by an oxygen atom perfectly solved the stability of the products. All the same, the change was unadvantageous for the anticandidous activity.

Various derivatives of 2-alkylsulfanyl-6-aminobenzothiazoles substituted at the amino group were found to inhibit photosynthetic processes in spinach chloroplasts and the chlorophyll production in algae Chlorella vulgaris [6 - 8]. Photosynthesis-inhibiting activity of the above compounds showed the socalled "cut off" effect - a decreased activity for the more lipophilic substances in the series.

\section{Results and Discussion}

This work, based on 14 new 3-(2-alkysulfanyl-6-benzothiazolylaminomethyl)-2-benzoxazolethiones (Scheme 1, Table 1) is focused on their inhibitory effect on the photosynthetic electron transport in spinach chloroplasts.

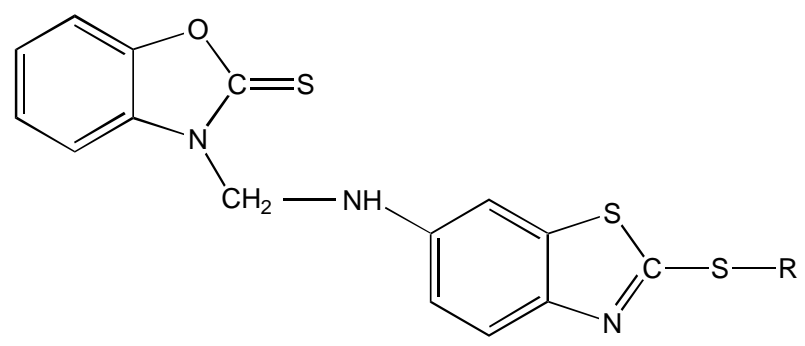

Scheme 1.

Table 1. Characterisation of the prepared 3-(2-alkylsulfanyl-6-benzothiazolylaminomethyl)-2benzoxazolethiones.

\begin{tabular}{|c|c|c|c|c|c|c|c|c|}
\hline \multirow[t]{2}{*}{ Comp. } & \multirow[t]{2}{*}{$\mathrm{R}$} & \multirow{2}{*}{$\begin{array}{c}\text { Formula } \\
\qquad \mathbf{M}_{r}\end{array}$} & \multicolumn{4}{|c|}{$W_{\mathrm{i}}\left(\right.$ calc) $\% / W_{\mathrm{i}}($ found $) \%$} & \multirow{2}{*}{$\begin{array}{c}\text { Yield } \\
\%\end{array}$} & \multirow{2}{*}{$\begin{array}{c}\text { M.p. } \\
{ }^{\circ} \mathrm{C}\end{array}$} \\
\hline & & & $\mathrm{C}$ & $\mathrm{H}$ & $\mathrm{N}$ & $S$ & & \\
\hline \multirow[t]{2}{*}{1} & \multirow[t]{2}{*}{$-\mathrm{CH}_{3}$} & $\mathrm{C}_{16} \mathrm{H}_{13} \mathrm{~N}_{3} \mathrm{OS}_{3}$ & 53.46 & 3.65 & 11.69 & 26.76 & \multirow[t]{2}{*}{88.9} & \multirow[t]{2}{*}{ 192-194 } \\
\hline & & 359.49 & 53.54 & 3.67 & 11.68 & 26.71 & & \\
\hline \multirow[t]{2}{*}{2} & \multirow[t]{2}{*}{$-\mathrm{C}_{2} \mathrm{H}_{5}$} & $\mathrm{C}_{17} \mathrm{H}_{15} \mathrm{~N}_{3} \mathrm{OS}_{3}$ & 54.67 & 4.05 & 11.25 & 25.75 & \multirow[t]{2}{*}{86.6} & \multirow[t]{2}{*}{$169.0-170.5$} \\
\hline & & 373.52 & 54.90 & 3.99 & 11.31 & 25.53 & & \\
\hline \multirow[t]{2}{*}{3} & \multirow[t]{2}{*}{$-\left(\mathrm{CH}_{2}\right)_{2} \mathrm{CH}_{3}$} & $\mathrm{C}_{18} \mathrm{H}_{17} \mathrm{~N}_{3} \mathrm{OS}_{3}$ & 55.99 & 4.40 & 10.79 & 24.71 & \multirow[t]{2}{*}{69.2} & \multirow[t]{2}{*}{$167.5-169.0$} \\
\hline & & 389.33 & 55.97 & 4.33 & 10.90 & 24.63 & & \\
\hline
\end{tabular}


Continuation of the Table 1.

\begin{tabular}{|c|c|c|c|c|c|c|c|c|}
\hline \multirow[t]{2}{*}{ Comp. } & \multirow[t]{2}{*}{$\mathrm{R}$} & \multirow{2}{*}{$\begin{array}{c}\text { Formula } \\
\qquad \mathrm{M}_{r}\end{array}$} & \multicolumn{4}{|c|}{$W_{\mathrm{i}}($ calc $) \% / W_{\mathrm{i}}($ found $) \%$} & \multirow{2}{*}{$\begin{array}{c}\text { Yield } \\
\%\end{array}$} & \multirow{2}{*}{$\begin{array}{l}\text { M.p. } \\
{ }^{\circ} \mathrm{C}\end{array}$} \\
\hline & & & $\mathrm{C}$ & $\mathrm{H}$ & $\mathrm{N}$ & S & & \\
\hline \multirow[t]{2}{*}{4} & \multirow[t]{2}{*}{$-\mathrm{C}_{3} \mathrm{H}_{5}^{\mathrm{a}}$} & $\mathrm{C}_{18} \mathrm{H}_{15} \mathrm{~N}_{3} \mathrm{OS}_{3}$ & 56.28 & 3.90 & 10.85 & 24.84 & \multirow[t]{2}{*}{84.0} & \multirow[t]{2}{*}{$155-157$} \\
\hline & & 387.31 & 56.29 & 3.89 & 10.94 & 25.12 & & \\
\hline \multirow[t]{2}{*}{5} & \multirow[t]{2}{*}{$-\left(\mathrm{CH}_{2}\right)_{3} \mathrm{CH}_{3}$} & $\mathrm{C}_{19} \mathrm{H}_{19} \mathrm{~N}_{3} \mathrm{OS}_{3}$ & 56.83 & 4.77 & 10.46 & 23.95 & \multirow[t]{2}{*}{85.0} & \multirow[t]{2}{*}{$159-160$} \\
\hline & & 401.57 & 56.54 & 4.67 & 10.30 & 23.93 & & \\
\hline \multirow[t]{2}{*}{6} & \multirow[t]{2}{*}{$-\mathrm{C}_{4} \mathrm{H}_{9}{ }^{\mathrm{b}}$} & $\mathrm{C}_{19} \mathrm{H}_{19} \mathrm{~N}_{3} \mathrm{OS}_{3}$ & 56.83 & 4.77 & 10.46 & 23.95 & \multirow[t]{2}{*}{63.4} & \multirow[t]{2}{*}{$166.5-168.5$} \\
\hline & & 401.57 & 56.98 & 4.75 & 10.47 & 24.26 & & \\
\hline \multirow[t]{2}{*}{7} & \multirow[t]{2}{*}{$-\left(\mathrm{CH}_{2}\right)_{4} \mathrm{CH}_{3}$} & $\mathrm{C}_{20} \mathrm{H}_{21} \mathrm{~N}_{3} \mathrm{OS}_{3}$ & 57.80 & 5.09 & 10.11 & 23.15 & \multirow[t]{2}{*}{70.9} & \multirow[t]{2}{*}{$150.0-152.5$} \\
\hline & & 415.60 & 57.97 & 5.10 & 10.16 & 23.29 & & \\
\hline \multirow[t]{2}{*}{8} & \multirow[t]{2}{*}{$-\mathrm{CH}\left(\mathrm{CH}_{2}\right)_{4}{ }^{\mathrm{c}}$} & $\mathrm{C}_{20} \mathrm{H}_{19} \mathrm{~N}_{3} \mathrm{OS}_{3}$ & 58.08 & 4.63 & 10.16 & 23.26 & \multirow[t]{2}{*}{74.9} & \multirow[t]{2}{*}{$179.5-181.5$} \\
\hline & & 413.58 & 58.12 & 4.56 & 10.14 & 23.28 & & \\
\hline \multirow[t]{2}{*}{9} & \multirow[t]{2}{*}{$-\left(\mathrm{CH}_{2}\right)_{5} \mathrm{CH}_{3}$} & $\mathrm{C}_{21} \mathrm{H}_{23} \mathrm{~N}_{3} \mathrm{OS}_{3}$ & 58.71 & 5.40 & 9.78 & 22.39 & \multirow[t]{2}{*}{82.0} & \multirow[t]{2}{*}{$156.5-158.5$} \\
\hline & & 429.63 & 58.78 & 5.44 & 9.78 & 22.03 & & \\
\hline \multirow[t]{2}{*}{10} & \multirow[t]{2}{*}{$-\left(\mathrm{CH}_{2}\right)_{6} \mathrm{CH}_{3}$} & $\mathrm{C}_{22} \mathrm{H}_{25} \mathrm{~N}_{3} \mathrm{OS}_{3}$ & 59.56 & 5.68 & 9.47 & 21.68 & \multirow[t]{2}{*}{86.7} & $149.5-151.0$ \\
\hline & & 443.65 & 59.68 & 5.60 & 9.46 & 21.85 & & \\
\hline 11 & $-\left(\mathrm{CH}_{2}\right)_{7} \mathrm{CH}_{3}$ & $\mathrm{C}_{23} \mathrm{H}_{27} \mathrm{~N}_{3} \mathrm{OS}_{3}$ & 60.36 & 5.95 & 9.18 & 21.02 & 87.4 & $151-152$ \\
\hline & & 457.68 & 60.48 & 5.89 & 9.08 & 21.40 & & \\
\hline 12 & $-\left(\mathrm{CH}_{2}\right)_{8} \mathrm{CH}_{3}$ & $\mathrm{C}_{24} \mathrm{H}_{29} \mathrm{~N}_{3} \mathrm{OS}_{3}$ & 61.11 & 6.20 & 8.91 & 20.39 & 79.5 & $143-145$ \\
\hline & & 471.71 & 61.11 & 6.22 & 8.88 & 20.31 & & \\
\hline 13 & $-\mathrm{CH}_{2}-\mathrm{C}_{6} \mathrm{H}_{5}$ & $\mathrm{C}_{22} \mathrm{H}_{17} \mathrm{~N}_{3} \mathrm{OS}_{3}$ & 60.66 & 3.93 & 9.65 & 22.08 & 75.6 & $151.5-153.5$ \\
\hline & & 435.59 & 60.46 & 3.88 & 9.56 & 21.87 & & \\
\hline 14 & $-\mathrm{C}_{2} \mathrm{H}_{4} \mathrm{OH}^{\mathrm{d}}$ & $\mathrm{C}_{17} \mathrm{H}_{15} \mathrm{~N}_{3} \mathrm{O}_{2} \mathrm{~S}_{3}$ & 52.42 & 3.88 & 10.79 & 24.70 & 68.0 & $165.0-167.5$ \\
\hline & & 389.52 & 52.13 & 3.83 & 10.87 & 24.69 & & \\
\hline
\end{tabular}

a allyl; ${ }^{\mathrm{b}} \mathrm{sec}$ - butyl; ${ }^{\mathrm{c}}$ cyclopentyl; ${ }^{\mathrm{d}}$ 2-hydroxyethyl.

The compounds have been synthesized by reaction of 2-alkylsulfanyl-6-aminobezothiazoles [1] with 3-hydroxymethyl-2-benzoxazolethione (Scheme 2). 
<smiles>[3H]Sc1nc2ccc(N)cc2s1</smiles><smiles>[R]Sc1nc2ccc(NCn3c(=S)oc4ccccc43)cc2s1</smiles>

Scheme 2.

The structures of the new compounds have been verified by ${ }^{1} \mathrm{H}$ NMR spectroscopy. The ${ }^{1} \mathrm{H}$ NMR spectra showed a doublet signal in the range of $5.79-5.77 \delta$ belonging to the $\mathrm{NCH}_{2}$ group with $\mathrm{J}=7.1$ - $6.8 \mathrm{~Hz}$, a multiplet of aromatic protons in the range of $7.9-6.9 \delta$ and the signals of alkyl groups, which were in accordance with the values of $\delta$ given in literature [9]. The signal of the $\mathrm{NH}$ group was partially overlapped by the aromatic signals.

The structures and the atomic charges of the synthesized compounds were calculated by quantum chemical AM1 method [12]. The calculated torsion angles between benzothiazolyl and benzoxazolyl parts were in the range $80-82^{\circ}$ and the alkylsulfanyl substituents were in the plane of the thiazolyl rings (Figure 1) except for cyclopentyl $\left(19^{\circ}\right)$ and benzyl $\left(89^{\circ}\right)$.

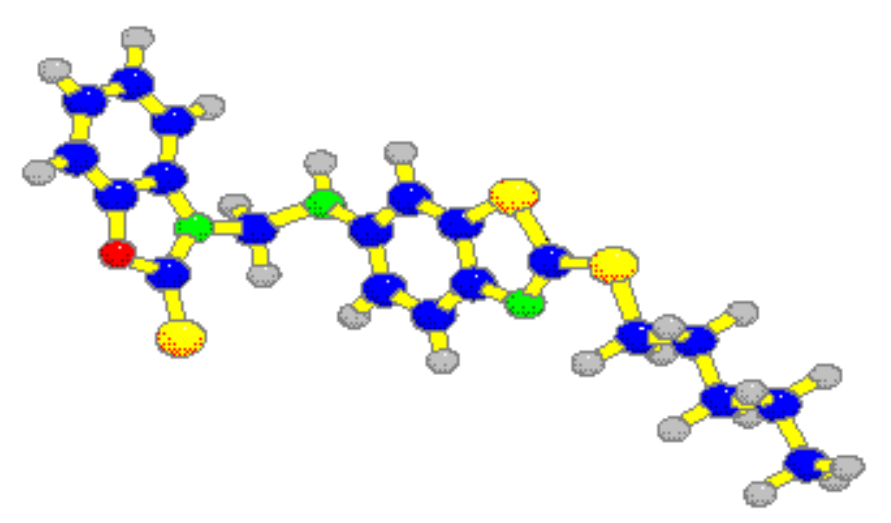

Figure 1. Scheme of the most active compound $\left(7, \mathrm{R}=-\left(\mathrm{CH}_{2}\right)_{4} \mathrm{CH}_{3}\right)$. Oxygen is indicated by red, nitrogen by green and sulphur by yellow colour. 
The changes of the atomic charges in all positions are very small. Atomic charges on $\mathrm{C}$ at position 6 are in the range $0.035-0.054$ and at position 2 in the range $-0.390--0.404$. Similar differences are on all atoms.

The inhibition of the photosynthetic electron transport in spinach chloroplasts was monitored by reduction of DCPIP in the presence of the studied compounds. The inhibitory activity has been expressed by $\mathrm{IC}_{50}$ values, i.e. by concentrations of the inhibitors causing $50 \%$ decrease of the oxygen evolution rate (OER) as compared with the untreated control sample (Table 2).

Table 2. Experimental values of $\mathrm{IC}_{50}$ of the studied compounds concerning oxygen evolution rate inhibition in spinach chloroplasts and calculated log $\mathrm{P}$.

\begin{tabular}{|c|c|c|}
\hline Comp. & $\log \mathrm{P}$ & $\mathrm{IC}_{50}{ }^{\mathrm{a}}\left(\mu \mathrm{mol} \mathrm{dm}{ }^{-3}\right)$ \\
\hline 1 & 3.64 & - \\
\hline 2 & 3.98 & 183 \\
\hline 3 & 4.45 & 74 \\
\hline 4 & 4.38 & 113 \\
\hline 5 & 4.85 & 77 \\
\hline 6 & 4.87 & 68 \\
\hline 7 & 5.25 & 56 \\
\hline 8 & 4.83 & 63 \\
\hline 9 & 5.64 & 75 \\
\hline 10 & 6.04 & 90 \\
\hline 11 & 6.43 & 124 \\
\hline 12 & 6.83 & 208 \\
\hline 13 & 5.42 & 63 \\
\hline 14 & 3.20 & - \\
\hline
\end{tabular}

${ }^{\mathrm{a}} \mathrm{IC}_{50}$ - molar concentration of the inhibitor causing $50 \%$ decrease of activity against control

The dependence of the photosynthesis-inhibiting activity on the calculated lipophilicity [13] of the studied compounds showed a quasi - parabolic course with the maximum activity for the pentyl derivative $\left(\mathrm{IC}_{50}=56 \mu \mathrm{mol} \mathrm{dm}{ }^{-3}\right.$ ). The least lipophilic compounds, methyl (1) and hydroxyethyl (14) derivatives did not inhibit oxygen evolution rate in spinach chloroplasts. It can be assumed that the passage of these compounds ( $\log \mathrm{P}=3.64$ and 3.20 respectively) through the lipophilic regions of 
thylakoid membranes is limited, what results in an insufficient number of inhibitors reaching the site of action in proteins situated on the inner side of thylakoid membrane. The decrease of the inhibitory activity with more lipophilic compounds $(\log \mathrm{P}>5.25)$ is probably connected with the too high lipophilicity of these compounds causing a limited penetrability through the hydrophilic regions of thylakoid membranes. Similar results were also obtained for the dependence of photosynthesis-inhibiting activity on the lipophilicity for several homologous series of $\mathrm{NH}_{2}$-substituted 2-alkylsulfanyl-6aminobenzothiazoles [6 - 8], including 3-(2-alkylsulfanyl-6-benzothiazolylamino-methyl)-2benzothiazolethiones [7, 8]. Based on the results obtained with EPR spectroscopy it has been shown that the site of action of the above benzothiazole derivatives in the photosynthetic apparatus of spinach chloroplasts is the donor side of photosystem 2, upstream of the site of diphenylcarbazide action, i.e. in the oxygen evolving complex [7]. Significant dependence of the OER inhibitory activity in spinach chloroplasts upon the lipophilicity of the compounds was found also with 2-(6-acetamidobenzothiazolethio) acetic acid esters [10], what means broadening of the variability of substituents for compounds with OER inhibiting activity by the alkoxycarbonylmethylsulfanyl group at position 2 of the benzothiazole skeleton.

The relatively small differences between charge densities of atoms do not allow meaningful correlation between biological activity and theoretical parameters. The parabolic dependence of the calculated $\log \mathrm{P}$ on the biological activity has high statistical significance.

$$
\begin{gathered}
\log \left(1 / \mathrm{IC}_{50}\right)=(2.553 \pm 0.245) \log \mathrm{P}-(0.240 \pm 0.026) \log ^{2} \mathrm{P}-2.578 \\
\mathrm{r}=0.965 \mathrm{~s}=0.189 \mathrm{~F}=58.0 \mathrm{n}=12
\end{gathered}
$$

The bilinear model [14, 15] gave statistically more significant results, the best value of the lipophilicity $\left(\log \mathrm{P}_{0}\right)$ was also calculated.

$$
\begin{aligned}
& \log \left(1 / \mathrm{IC}_{50}\right)=(0.821 \pm 0.075) \log \mathrm{P}-(1.276 \pm 0.107) \log (\beta+1)+0.540 \\
& \mathrm{r}=0.971 \quad \mathrm{~s}=0.049 \mathrm{~F}=74.9 \mathrm{n}=12 \quad \log \mathrm{P}_{0}=5.18 \quad \beta=1.202 .10^{-5}
\end{aligned}
$$

The F-test value is statistically significant at the $99.5 \%$ level of probability. The biological efficiency of the molecule decreases when the value calculated for $\log \mathrm{P}$ is lower or higher than the value calculated for $\log \mathrm{P}_{0}$. The compound $7\left(\mathrm{R}=-\left(\mathrm{CH}_{2}\right)_{4} \mathrm{CH}_{3}\right)$ has the best biological activity.

\section{Experimental}

\section{General}

The starting 2-alkylsulfanyl-6-aminobenzothiazoles were synthesized according to [1]. 3Hydroxymethyl-2-benzoxazolethione was prepared by the method described in [11]. Melting points were determined on a Kofler hotstage apparaturs and are uncorrected. ${ }^{1} \mathrm{H}$ NMR spectra were obtained on a TESLA BS 587 spectrometer (80 MHz) in deuterated dimethylsulfoxide (DMSO) solution. Tetramethylsilane was used as inner standard.

The inhibitory effect of the studied compounds on the rate of photosynthetic electron transport in 
spinach chloroplasts was investigated spectrophotometrically (Specord UV VIS, Zeiss Jena, Germany) in the presence of electron acceptor 2,6-dichlorophenol-indophenol (DCPIP) immediately after treating the chloroplast suspension with the inhibitor. The measurements were carried out in phosphate buffer (20 mmol, $\mathrm{pH}=7.2)$ containing sucrose $\left(0.4 \mathrm{~mol} \mathrm{dm}^{-3}\right), \mathrm{MgCl}_{2}\left(5 \mathrm{mmol} \mathrm{dm}{ }^{-3}\right)$ and $\mathrm{NaCl}\left(15 \mathrm{mmol} \mathrm{dm}^{-}\right.$ $\left.{ }^{3}\right)$ and the chlorophyll content in the suspension was $30 \mathrm{mg} \mathrm{dm}^{-3}$. The samples were irradiated $(\sim 100 \mathrm{~W}$ $\mathrm{m}^{-2}$ ) from $10 \mathrm{~cm}$ distance with a halogen lamp $(250 \mathrm{~W})$ using water filter to exclude warming of the samples. The applied DMSO concentration (up to $5 \%$ ) did not affect the oxygen evolution rate.

Structures and atomic charges were calculated by quantum chemical AM1 method with standard parametrization and full optimalization (keyword PRECISE) [12]. Log P were found by Crippen's method [13].

\section{3-(2-Alkylsulfanyl-6-benzothiazolylaminomethyl)-2-benzoxazolethiones $\mathbf{1}$ - 14}

The mixture of 2-alkylsulfanyl-6-aminobenzothiazole $(0.02 \mathrm{~mol})$ and 3-hydroxymethyl-2benzoxazolethione $(0.02 \mathrm{~mol}, 3.4 \mathrm{~g})$ was refluxed in ethanol $\left(50 \mathrm{~cm}^{3}\right)$ for $5 \mathrm{~min}$. After cooling the reaction mixture to $4{ }^{\circ} \mathrm{C}$ the product was filtered off and washed with the mixture of isohexane and cyklohexane $(2: 1)$.

Acknowledgements: Our thanks are due to Dr. E. Solcaniova and Dr. E. Greiplova for ${ }^{1} \mathrm{H}$ NMR spectra and elemental analysis (Institute of Chemistry, Faculty of Natural Sciences, Comenius University, Bratislava). Financial support for this research by the Slovak Grant Agency (grant No. 1/4013/97 and 1/5085/98) gratefully acknowledged.

\section{References and Notes}

1. Sidoova, E.; Odlerova, Z.; Volna, F.; Blockinger, G. Chem. Zvesti 1979, 33, 830.

2. Sidoova, E. Chem. Listy 1993, 87 (Supplementum), 231.

3. Sidoova, E.; Bujdakova, H.; Kralova, K. SK Pat. 278095, 1995.

4. Bujdakova,; Kralova, K.; Sidoova, E. Pharmazie 1994, 49, 375.

5. Bujdakova,; Kralova, K.; Sidoova, E. Pharmazie 1995, 50, 156.

6. Kralova, K.; Sersen, F.; Sidoova, E. Chem. Papers 1992, 46, 348.

7. Kralova, K.; Sersen, F.; Sidoova, E. Gen. Physiol. Biophys. 1993, 12, 421.

8. Kralova, K.; Sersen, F.; Loos, D.; Sidoova, E. Chem. Papers 1994, 48, 198.

9. Gunther, H. NMR Spectroscopy, John Wiley, Chichester 1995, 102.

10. Sidoova, E.; Kralova, K.; Loos, D. Molecules 1998, 3, 135.

11. Stavrovskaya, V.I.; Kolosova, M.O. Zh. Obshch. Khim. 1960, 30, 689.

12. AMPAC 5.0, 1994 Semichem, 7128 Summit, KS 66216.

13. Ertl, P. Chem. Listy 1992, 86, 465. 
14. Kubyni, H. Arzneim.-Forsch. (Drug. Res.) 1976, 26, 1991.

15. Kubyni, H.; Kehrhan, O.H. Arzneim.-Forsch. (Drug. Res.) 1978, 28, 598.

Samples Availability: Available from the authors.

(C) 1999 by Molecular Diversity Preservation International (MDPI) 